\title{
FEATURE Improving conservation practices programming to protect water quality in agricultural watersheds: Lessons learned from the National Institute of Food and Agriculture-Conservation Effects Assessment Project
}

Deanna Osmond, Don Meals, Dana Hoag, Mazdak Arabi, Al Luloff, Greg Jennings, Mark McFarland, Jean Spooner, Andrew Sharpley, and Dan Line

$\mathbf{N}$

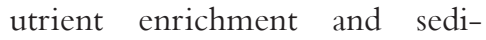
mentation of water resources is a significant problem in the United States and globally (Carpenter et al. 2011; Dubrovsky et al. 2010; Hilton et al. 2006). Specifically, in the United States, over 6,908 water bodies are listed as being nutrient impaired and 6,165 are sediment impaired (USEPA 2012). Agricultural nonpoint source pollution contributes, in part, to impaired water resources in many of these watersheds (NRC 2008; USEPA 2010).

Conservation practices, including conservation tillage, nutrient management, and riparian buffers, are routinely used to reduce off-site losses of sediment, nutrients, pesticides, and bacteria from agricultural operations. Many research studies, generally conducted at the plotor field-scale, report ranges in effectiveness of such conservation practices, from being negative to $100 \%$ effective (Gagnon et al. 2004; Gagnon et al. 2008; Jokela et al. 2004; Line et al. 2001; Richards and Baker 2002; Schnepf and Cox 2006; Sharpley et al. 2006; Shepard 2005; Smith et al. 2006).

Documentation of combined practice impacts on water quality at the watershed scale has been more difficult than in plot or field-scale studies. The Black

Deanna Osmond is professor in the Department of Soil Science, Greg Jennings is professor, Jean Spooner is extension professor, and Dan Line is extension specialist in the Department of Biological and Agricultural Engineering, North Carolina State University, Raleigh, North Carolina. Don Meals is private consultant and owner of Ice.Nine Environmental Consulting, Burlington, Vermont. Dana Hoag is professor in the Department of Agricultural and Resource Economics and Mazdak Arabi is assistant professor in the Department of Civil and Environmental Engineering, Colorado State University, Ft. Collins, Colorado. Al Luloff is professor in the Department of Agricultural Economics, Sociology, and Education, The Pennsylvania State University, University Park, Pennsylvania. Mark McFarland is professor in the Department of Soil and Crop Sciences, College Station, Texas. Andrew Sharpley is professor in the Department of Crop, Soil, and Environmental Sciences, University of Arkansas, Fayetteville, Arizona.
Creek Project in northeastern Indiana and the Model Implementation Program (MIP) promoted by the USDA and US Environmental Protection Agency (USEPA) were developed in the late 1970s to evaluate the effectiveness of agricultural practices on water quality at the watershed scale (Dressing et al. 1983; Morrison and Lake 1983). The Rural Clean Water Program (RCWP), another joint effort by USDA and USEPA, was developed using lessons from the MIP. The RCWP was a nationwide effort to relate implementation of programs of conservation practices to watershed water quality (Gale et al. 1993). Much was learned from this initiative and led to further programs, such as the USEPA Section 319 National Nonpoint Source Monitoring Program (NNPSMP) (Spooner et al. 2011); some of the projects that are part of this protocol were able to document effectiveness of grazing management, nutrient management, and stream restoration at the watershed scale.

More recently, USDA, through the National Institute of Food and Agriculture (NIFA) and the Natural Resources Conservation Service (NRCS), funded 13 watershed-scale agricultural projects (2004 to 2006) to focus on relating water quality change to conservation practice implementation on crop and pasture land. This project, NIFA-Conservation Effects Assessment Project (CEAP), was one of several overall USDA CEAP initiatives. The USDA CEAP was created in 2003 to understand and optimize environmental benefits of conservation practices implemented via selected USDA conservation programs, with the overall goal of improving efficacy of conservation practices and programs by quantifying conservation effects and providing the science and education base needed to improve future conservation planning, implementation, management decisions, and policy (Duriancik et al.2008; Maresch et al.2008).

Specifically, NIFA-CEAP was designed to evaluate the impacts of interactions among conservation practices and their biophysical setting on water quality at a watershed scale. The evaluation also focused on social and economic factors that influence implementation and maintenance of practices (USDA NIFA 2012). Successful applicants for the NIFA-CEAP protocol worked in small watersheds (8- to 12-digit US Geological Survey Hydrologic Unit Code), with a long-term $(>5$ years) record of water quality data to enable retrospective analysis of conservation practice implementation. Most conservation efforts were implemented by farmers through USDA or state cost share, USEPA Section 319 funds, regional watershed programs, and/or from their own funds, and this practice information was often hard to obtain. Two of the watersheds (Iowa and New York) were initiated as part of another protocol-USEPA 319 NNPSMP. The following four issues were expected to be addressed by each of the 13 NIFA-CEAP watershed studies:

1. How the timing, location, and suite of implemented agricultural conservation practices affect water quality at the watershed scale?

2. How conservation practices implemented in a watershed interact with respect to their effects on water quality?

3. What social and economic factors facilitate or impede implementation of conservation practices?

4. What is the optimal set and placement of conservation practices within the watershed to achieve water quality goals? (Application of watershed models was expected to address this question.)

Each NIFA-CEAP project made contributions to the understanding of the effectiveness of conservation practices for improving water quality at the watershed scale (see references in Chapters 9 to 21 in Osmond et al. 2012). As the 13 watershed studies were terminating, however, it was essential to take a broad, thorough, and systematic look at each project's results in order to synthesize lessons and derive key principles. Such a synthetic approach can guide future watershed management efforts and provide key policy makers with 
information to increase the environmental and economic effectiveness of conservation programs. The purpose of this paper is to describe the top 15 lessons learned from the synthesis of the NIFA-CEAP studies (Osmond et al. 2012).

\section{SYNTHESIS STRATEGY}

To collect information from the diverse NIFA-CEAP watershed studies, a synthesis template was developed in association with NIFA-CEAP watershed investigators and the multiagency CEAP steering team. The template had to be robust to account for large watershed study differences (figure 1 and table 1). As each NIFA-CEAP study was completed, multiple sources of information (e.g., publications, presentations, fact sheets) were collected from individual projects in order to provide information used in the template. A site visit, including key informant interviews, was then conducted. A key informant interview questionnaire was used at each watershed location, with a minimum of 6 to a maximum of 26 interviewees (Luloff et al. 2012). Interviews were held with 34 farmers, 33 university/extension affiliates, 23 representatives of federal agencies, 10 representatives of state agencies, 28 representatives of local agencies, 24 representatives of local businesses or newspapers, 11 local residents, and 11 elected officials, for a total of 174 key informants. Information from the templates was used to produce a brief NIFA-CEAP narrative for each of the 13 projects (Chapters 9 to 21 in Osmond et al. 2012). Each narrative was developed iteratively with watershed investigators and personnel. Watershed narratives, along with the key informant interviews, were used to develop lessons for each project, and ultimately all information was synthesized into a series of lessons learned.

\section{LESSONS LEARNED}

It is critically important to heed the advice of George Santayana, "those who cannot remember the past are condemned to repeat it," because many of the lessons learned in the NIFA-CEAP were the same lessons identified in prior watershedscale projects, such as the RCWP (Gale et al. 1993), and published in books and

\section{Figure 1}

National Institute of Food and Agriculture-Conservation Effects Assessment Project locations (Osmond et al. 2012).

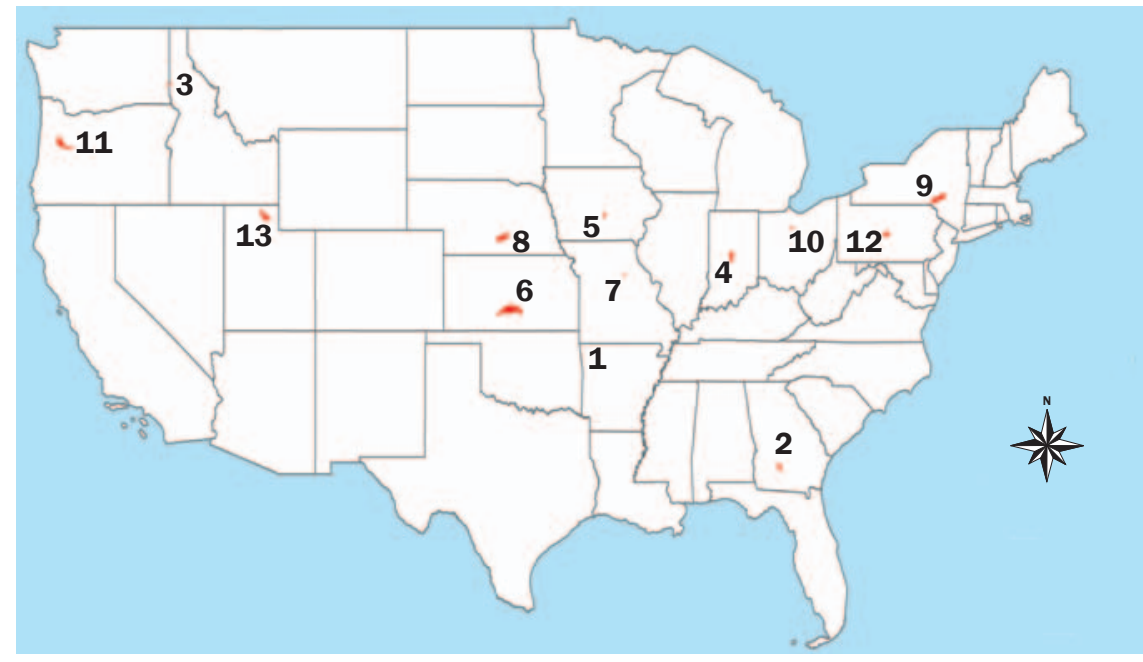

\section{Legend}

1. Lincoln Lake, Arkansas

2. Little River, Georgia

3. Paradise Creek, Idaho

4. Eagle Creek, Indiana

5. Walnut Creek/Squaw Creek, lowa
6. Cheney Lake, Kansas

7. Goodwater Creek, Missouri

8. Phase III: Central Platte Natural Resources District, Nebraska

9. Cannonsville Reservoir, New York
10. Rock Creek, Ohio

11. Lower Calapooia, Oregon 12. Spring Creek, Pennsylvania

13. Little Bear River, Utah

NIFA-CEAP watershed Scale: 1:10,000,000 articles (Sanders and Cahill 1999). The science from these previously funded federal programs was not translated into practice as the lessons were rarely incorporated into state and federal conservation programs. With dwindling federal and state financial resources and growing calls for accountability, it is imperative that NIFACEAP and past watershed-scale project lessons learned be incorporated into current and future agricultural conservation programs, policies, and agency protocol to improve environmental outcomes while reducing cost.

The 15 most important lessons that were identified and documented through synthesis of the 13 NIFA-CEAP studies are presented below. More detailed information on each lesson, as well as additional lessons, can be found in Osmond et al. 2012; corresponding chapters are identified next to each lesson.

Lesson 1. Conservation planning must be done at the watershed scale with sufficient water quality data and may require modeling information. Most conservation planning is conducted at the county level rather than at the watershed scale and therefore may be unable to solve water- shed problems, as was found for several projects (Chapters 3 and 4).

Lesson 2. Conservation efforts must be directed at the appropriate target; verify the pollutant(s) of concern and the sources of the pollutant(s) before taking any action. The predominant conservation practices in several NIFA-CEAP watersheds were designed to reduce sediment (conservation tillage, grassed waterways, terraces, and drains); although, nitrogen $(\mathrm{N})$ was the primary pollutant of concern, and some of these practices may actually increase $\mathrm{N}$ losses. All of the NIFA-CEAP watersheds, except one (Kansas), concerned about sediment from upland erosion determined that most of the sediment ( $75 \%$ or more) was derived from streambanks and stream channels; therefore, the source of the pollutant (streams) was not being treated by upland sediment-reducing practices (Chapters 3, 4, 11, 12, and 14).

Lesson 3. Critical source areas (locations in the watershed that deliver a disproportionate amount of pollutant) must be identified and conservation practice implementation should be targeted to those areas. Three projects (Kansas, Missouri, and Utah) identified critical 
Table 1

Characteristics of the 13 National Institute of Food and Agriculture-Conservation Effects Assessment Project Watersheds: State, water resource of concern, pollutant of concern, and land use.

\begin{tabular}{|c|c|c|c|c|}
\hline State & Water resource(s) & Pollutant(s) of concern & Land use & Watershed area $\left(\mathrm{km}^{2}\left[\mathrm{mi}^{2}\right]\right)$ \\
\hline Georgia & Little River & $\mathrm{N}, \mathrm{P}$ & Cropland & 334 (129) \\
\hline Indiana & Eagle Creek and Reservoir & Sediment, $\mathrm{P}, \mathrm{N}$, Atrazine, E. coli & Cropland, development & $420(162)$ \\
\hline lowa & Walnut Creek/Squaw Creek & $\mathrm{N}$ & Cropland & $53(21) / 63(24)$ \\
\hline Nebraska & $\begin{array}{l}\text { Phase III, Central Platte } \\
\text { Natural Resource District }\end{array}$ & $\mathrm{N}$ & Irrigated cropland & $559(216)$ \\
\hline New York* & Cannonsville Reservoir & $\mathrm{P}$ & Cropland, animals & $1,179(455)$ \\
\hline Ohio & Rock Creek & Sediment, $\mathrm{P}$ & Cropland & $90(35)$ \\
\hline Oregon & Calapooia River & Temperature, E. coli & Cropland, animals, development & $962(372)$ \\
\hline
\end{tabular}

* Water quality data are from a paired watershed study conducted on 165 ha (408 ac) and funded by the US Environmental Protection Agency Section 319 Nonpoint Source Monitoring Program.

Notes: $\mathrm{N}=$ nitrogen. $\mathrm{P}=$ phosphorus.

source areas using different methods during the NIFA-CEAP (Chapters 14, 15, and 21 ) and found that only about $25 \%$ of the conservation practices had been placed in critical source areas (Chapter 3).

Lesson 4. It is essential to understand watershed farmers' attitudes toward agriculture and conservation practices to promote adoption as well as to identify and understand the attitudes of potential "downstream" partners/stakeholders. Many socioeconomic factors affect conservation practice adoption and must be considered when working with farmers to implement practices. Two watersheds (Kansas and New York) partnered with cities using the water resources, and the cities provided additional funding that helped promote and pay for conservation practice adoption (Chapters 2, 5, and 6).

Lesson 5. Postimplementation maintenance and sustained use of conservation practices must be ensured. Several projects (Kansas, Pennsylvania, and Utah) documented discontinuation of practices, especially management practices such as nutrient management (Chapters 14, 20, and 21). This was due to generational transfers or changes in land ownership and/or lack of interest in continuation of the practice (Chapters 2, 3, and 6).
Lesson 6. Technical assistance to farmers is most effective when delivered by a trusted local contact, including peer farmers, and is highly people intensive. Farmer-to-farmer programs in New York and Kansas were very effective in delivering conservation practice technical assistance, but required outside funding as did the hiring of an extension agent in the Arkansas NIFA-CEAP (Chapters 9, 14, and 17). The agent worked directly with a small group of farmers to encourage adoption of nutrient management (Chapters 2, 6, 7, and 9).

Lesson 7. Reduced funding has eroded the ability of USDA NRCS, land grant university extension services, and soil and water conservation districts to deliver effective programming to farmers. Many farmers, agency personnel, and other watershed groups noted the decrease in agency personnel due to reduced funding and recognized that this has affected conservation program delivery (Chapters 2 and 6).

Lesson 8. Economic incentives, and potentially incentives greater than current levels, will often be required for adoption of conservation practices not obviously profitable or compatible with current farming systems. The most disliked con- servation practice was a riparian buffer, followed by nutrient management. These practices were not seen as providing farm revenue and would need to be encouraged through economic incentives, such as cost share and other program eligibility or regulatory structures (Chapters 2 and 6).

Lesson 9. Conservation practice adoption is a multidimensional choice and, although economics are exceptionally important, many other factors affect the decision-making process. From discussions with farmers during the key informant interviews, it was very clear that a range of factors affected decisions about conservation practices, but the overriding issues were time management, profit, and yields. Other factors, such as family dynamics, also may affect practice implementation but are more subtle and difficult to discern (Chapters 2 and 6).

Lesson 10. Projects that conduct water quality monitoring must establish monitoring systems that are designed to specifically evaluate response to conservation treatment(s) and ensure such projects include necessary resources and expertise. Because the NIFA-CEAP studies were retrospective, in some watersheds water quality monitoring was not designed to relate conservation practices to water 
quality, there were insufficient data, or the watershed size was too large to demonstrate change during the monitoring period. The three paired watershed studies were all able to demonstrate water quality change during the monitoring period, which was usually $>10$ years (Chapter 4 ).

Lesson 11. To link water quality response to land treatment changes, conservation practices must be monitored as intensively as water quality and at the same temporal and spatial scales. Obtaining land treatment data at the appropriate temporal and spatial scales can be even more challenging than water quality monitoring. For instance, if the objective is to relate $\mathrm{N}$ reductions to nutrient management, then it is essential to know the timing, rate, and placement of the fertilizer, the current crop, and other management practices for every field in the watershed. To obtain this level of detailed information, a representative sample of farmers will need to be surveyed annually, which is expensive and may cause survey fatigue among landowners (Chapter 4).

Lesson 12. Knowledge of land use, management, and conservation practices is absolutely essential to understand effectiveness of conservation programs. Such data are often unavailable due to confidentiality restrictions or are incomplete (Chapters 3 and 4). The 2002 Farm Bill made it very difficult to obtain information on federally funded conservation practices. As a consequence, many of the NIFA-CEAP watersheds had difficulty obtaining information on conservation practices from USDA NRCS, although most were eventually successful. The Indiana NIFA-CEAP project determined that they needed three sources of information-farmer survey, USDA NRCS derived, and aerial survey-in order to create a robust conservation practice dataset, after duplicate data were excluded (Chapter 13).

Lesson 13. Unless adequate water quality and land treatment and use monitoring is planned for many years, including preconservation practice baseline monitoring, conservation implementation projects should NOT conduct water quality monitoring because they would be unlikely to document water quality change. Water quality monitoring requires significant technical expertise and financial resources over a long period of time (often $>20$ years) due to the variability of water quality data and lag times associated with pollutant removal from the water resource (Meals et al. 2010; Chapter 4). Project resources may be wasted on inadequate monitoring that fails to meet project objectives.

Lesson 14. Watershed models are very complex. Select the correct model(s) and modify to suit watershed characteristics if necessary. Ensure sufficiently trained personnel, well-calibrated models, and adequate water quality and land treatment data, including spatial and temporal changes of these data. Not all projects were able to successfully use water quality models; in one case, the model could not represent overland soil losses. Several of the NIFA-CEAP studies (e.g., Missouri and New York) modified the Soil and Water Assessment Tool (SWAT) to better represent hydrologic and water quality processes (Chapters 15 and 17). Idaho combined models to translocate sediment from the fields and through the streams (Chapter 12). Some projects (e.g., Kansas and Pennsylvania) compared models and found different results (Chapters 14 and 20). All of this requires modelers with experience and sufficient water quality data to calibrate and evaluate the models in order for results to be meaningful (Chapter 5).

Lesson 15. The scientific basis of modeling is still evolving. There are many deficiencies in our knowledge and in existing modeling tools for representation of critical natural processes and key management actions at the watershed scale. In general, the complexity and nonlinear nature of watershed processes overwhelm the capacity of existing modeling tools to reveal the water quality impacts of conservation practices. Also, not all conservation practices could be adequately represented in the models. Finally, due either to problems in the modeling or in the water quality data, or both, the models grossly overestimated the effectiveness of conservation practices (Chapters 4, 5, and 8).

\section{CURRENT APPLICATION}

Three USDA CEAP protocols-Cropland Studies, Agricultural Research Service watersheds, and NIFA watersheds-have all documented that uplands have been well treated to reduce erosion, although in some watersheds, such as Cheney Lake (Kansas), soil erosion from cropland is still problematic. Soil loss has been increasingly reduced as more and more acres are farmed using conservation tillage. Transformation away from conventional tillage has occurred due to state and federal conservation programs, technological changes (no-till planters [equipment], improved crop varieties [genetics], and herbicides), and lowered cost and labor of conservation tillage.

There was little indication, however, that progress has been made in reducing nutrient losses from agricultural systems in the NIFA-CEAP. Nutrient enrichment is degrading estuaries (e.g., Chesapeake Bay, Albermarle-Pamlico Sound), bays (e.g., Tampa Bay), and larger coastal areas (e.g., the Gulf of Mexico) (Dubrovsky et al. 2010; NRC 2008; USEPA 2011). In addition, many smaller lakes and reservoirs also are affected, resulting in impairments to drinking water, recreation, and other beneficial uses (Richards et al. 2010; USEPA 2012). Lessons from NIFA-CEAP suggest that controlling nutrients will be more difficult than controlling sediment for several major reasons:

1. Farmers more frequently implement conservation practices to control pollutants they can see. For example, farmers can see soil losses and have great impetus to control soil erosion either through conservation tillage or through terraces and grassed waterways.

2. Farmers tend to abandon and discontinue management practices (e.g., nutrient management) more frequently than structural practices (e.g., terraces).

3. Farmers often view routine nutrient applications as a way to avoid risk. In the absence of soil testing to credit available nutrients (such is often the case with $\mathrm{N}$ ), rates may exceed plant needs, although this does not suggest overapplication relative to yield goal.

4. Conservation practices may have antagonistic outcomes. Examples include grassed waterways and terraces or conservation tillage. Several NIFACEAP studies indicated that terraces and grassed waterways reduced soil loss but increased nitrate leaching. Another 
watershed project showed that removal of terraces to accommodate larger notill machinery increased erosion.

5. Farmers have been installing drain tiles throughout the Midwest and even the south at unprecedented rates. Drain tiles change hydrology, increase the contributing source area, and provide a short circuit for nutrients, including phosphorus, to move into streams.

6. Marginal lands (pastures) and Conservation Reserve Program lands are being transformed into field crops, such as corn and soybeans. The Iowa NIFA-CEAP documented increases in nitrate-N concentrations of $1,200 \%$ for subbasins where Conservation Reserve Program lands were transformed back to cropland.

7. Climate change models and two NIFA-CEAP studies suggest there will be increased fall rainfall, which may increase nutrient loading due to greater runoff and leaching.

The way forward for both improved environmental outcomes and economic viability in agricultural watersheds is for everyone-farmers, agribusiness, agency personnel, nongovernmental organizations, scientists, and citizens-to apply the lessons provided from this and other watershed studies and forge working partnerships to protect water quality.

\section{ACKNOWLEDGEMENTS}

The authors are grateful for the funding supplied by USDA National Institute of Food and Agriculture and USDA Natural Resources Conservation Service to conduct the synthesis study under Agreement No. 2007-51130-18575. Any opinions, findings, conclusions, or recommendations expressed in this publication are those of the author(s) and do not necessarily reflect the view of the USDA, which is an equal opportunity provider and employer. The authors especially want to thank all NIFA-CEAP watershed researchers and personnel for their help with the synthesis study and Lisa Duriancick of USDA Natural Resources Conservation Service.

\section{REFERENCES}

Carpenter, S.R., E.H.Stanley, and M.J.Vander Zanden. 2011. State of the world's freshwater ecosystems: physical, chemical and biological changes. Annual Review of Environmental Resources 36:75-99.

Dressing, S.A., J.M., Kreglow, R.P. Maas, F.A. Koehler, FJ. Humenik, and W.K. Snyder. 1983. The Model Implementation Program: Lessons Learned from
Agricultural Water Quality Projects. Washington, DC: USDA and United States Environmental Protection Agency.

Dubrovsky, N.M., K.R. Burow, G.M Clark, J.M. Gronberg, P.A. Hamilton, K.J. Hitt, D.K. Mueller, M.D. Munn, B.T. Nolan, L.J. Puckett, M.G. Rupert,T.M. Short, N.E. Spahr, L.A. Sprague, and W.G Wilber. 2010. The Quality of our Nation's Waters-Nutrients in the Nation's Streams and Groundwater, 1992-2004. US Geological Survey Circular 1350. http://water.usgs.gov/nawqa/ nutrients/pubs/circ1350.

Duriancik, L.F., D. Bucks, J.P. Dobrowolski, T. Drewes, S.D. Eckles, L. Jolly, R.L. Kellogg, D. Lund, J.R. Makuch, M.P. O’Neill, C.A. Rewa, M.R. Walbridge, R. Parry, and M.A. Weltz. 2008. The first five years of the Conservation Effects Assessment Project. Journal of Soil and Water Conservation 63(6):185A-197A, doi:10.2489/ jswc.63.6.185A.

Gagnon, S.R., J.R. Makuch, and T.J. Sherman. 2004. Environmental Effects of U.S. Department of Agricultural Conservation Programs: A Conservation Effects Assessment Project (CEAP) Bibliography. Special Reference Briefs Series no. SRB 2004-01. Beltsville, MD: Water Quality Information Center, National Agricultural Library, USDA Agricultural Research Service.

Gagnon, S.R., J.R. Makuch, and C.Y. Harper. 2008. Effects of Agricultural Conservation Practices on Fish and Wildlife: A Conservation Effects Assessment Project (CEAP) Bibliography. Special Reference Briefs Series no. SRB 200801. Beltsville, MD: Water Quality Information Center, National Agricultural Library, USDA Agricultural Research Service.

Gale, J.A., D.E. Line, D.L. Osmond, S.W. Coffey, J. Spooner, J.A. Arnold, T.J. Hoban, and R.C. Wimberley. 1993. Evaluation of the Experimental Rural Clean Water Program. National Water Quality Evaluation Project. EPA-841-R-93-005. Raleigh, NC: North Carolina State University, Biological and Agricultural Engineering Department, North Carolina State University Water Quality Group.

Hilton, J., M. O’Hare, M.J. Bowes, and I. Jones. 2006. How green is my river? A new paradigm of eutrophication in rivers. Science of the Total Environment 365:66-83.

Jokela, W.E., J.C. Clausen, D.W. Meals, and A.N. Sharpley. 2004. Effectiveness of agricultural best management practices in reducing phosphorous loading to Lake Champlain. In Lake Champlain: Partnerships and Research in the New Millennium, eds. T.O. Manley, P.L. Manley, and T.B. Mihuc, 39-53. Dordrecht, The Netherlands: Kluwer Academic Publishers.
Line, D.E., D.L. Osmond, R.A. McLaughlin, L.A. Lombardo, G.L. Grabow, D. Frederick, and J. Spooner. 2001. Nonpoint sources. Water Environment Research 73(5):1468-1509.

Luloff,A.E., D.L Hoag, D.L. Osmond, B.R.Woods,J.S. Gordon, J. Gruver, K. Roka, C.M. Raboanarielina, C. Longmire, M. Ward, and J.L. Weigle. 2012. NIFA-CEAP key informant survey: What farmers, agency personnel, and stakeholders think. In How to Build Better Agricultural Conservation Programs to Protect Water Quality: The NIFACEAP Experience, eds. D. Osmond,D. Meals, D. Hoag, and M. Arabi. Ankeny, IA: Soil and Water Conservation Society.

Maresch, W., M.R. Walbridge, and D. Kugler. 2008. Enhancing conservation on agricultural landscapes: A new direction for the Conservation Effects Assessment Project. Journal of Soil and Water Conservation 63(6):198A-203A, doi:10.2489/jswc.63.6.198A.

Meals, D.W., S.A. Dressing, and T.E. Davenport. 2010. Lag time in water quality response to best management practices: A review. Journal of Environmental Quality 39:85-89.

Morrison, J., and J. Lake. 1983. Environmental Impact of Land Use on Water Quality Black Creek Project-Final Report. Fort Wayne, IN: Allen County Soil and Water Conservation District.

NRC (National Research Council). 2008. Nutrient Control Actions for Improving Water Quality in the Mississippi River Basin and Northern Gulf of Mexico. Committee on the Mississippi River and the Clean Water Act: Scientific, Modeling and Technical Aspects of Nutrient Pollutant Load Allocation and Implementation. Washington, DC: National Research Council of the National Academies. http://www.nap.edu/catalog/125 44.html.

Osmond, D.L., D.W. Meals, D.LK. Hoag, and M. Arabi. 2012. How to Build Better Agricultural Conservation Programs to Protect Water Quality: The National Institute of Food and Agriculture-Conservation Effects Assessment Project Experience. Ankeny, IA: Soil and Water Conservation Society.

Richards, P.R., and D.B. Baker. 2002. Trends in water quality in LEASEQ rivers and stream (Northwester Ohio), 1975-1995. Journal of Environmental Quality 31:90-96.

Richards, R.P., D.B. Baker, J.P. Crumrine, and A.M. Stearns. 2010. Unusually large loads in 2007 from the Maumee and Sandusky Rivers, tributaries to Lake Erie. Journal of Soil and Water Conservation 65(6):450-462.

Sanders, D., and D. Cahill. 1999. Where incentives fit in soil conservation programs. In Incentives in Soil Conservation: From Theory to Practice, eds. 
D.W. Sanders, P. C. Huszar, S. Sombatpanit, and T. Enters, 11-24. Enfield, NH: World Association of Soil and Water Conservation, Science Publishers, Inc.

Schnepf, M., and C. Cox (eds). 2006. Environmental Benefits of Conservations Practices on Cropland: the Status of Our Knowledge. Ankeny, IA: Soil and Water conservation Society.

Sharpley, A.N., T.C. Daniel, G. Gibson, L. Bundy, M. Cabrera, J.T. Sims, R. Stevens, J. Lemunyon, P.J.A. Kleinman, and R. Parry. 2006. Best Management Practices to Minimize Agricultural Phosphorus Impacts on Water Quality. USDA ARS Publication 163. Washington, DC: US Government Printing Office.

Shepard, R. 2005. Nutrient management planning: Is it the answer to better management? Journal of Soil and Water Conservation 60:171-176.

Smith, T.A., D.L. Osmond, and J.W. Gilliam. 2006. Riparian buffer width and nitrate removal in a lagoon-effluent irrigated agricultural area.Journal of Soil and Water Conservation 61(5):273-281.

Spooner,J., D.E. Line, D. Meals, G.L. Grabow, and D.L. Osmond. 2011. Summary Report: Section 319 National Monitoring Program Projects. Nonpoint Source Watershed Project Studies. Raleigh, NC: North Carolina State University, Biological and Agricultural Engineering Department, North Carolina State University Water Quality Group. http://www.bae.ncsu.edu/programs/extension/ wqg/319monitoring/11rept319/index.htm.

USDA NIFA (National Institute of Food and Agriculture). 2012. NIFA Conservation Effects Assessment Project. http://www.usawaterquality. org/funded_projects/CEAP/default.html.

USEPA (US Environmental Protection Agency). 2010. Guidance for Federal land management in the Chesapeake Bay Watershed. Chapter 2: Agriculture. EPA841-R-10-002. Washington, DC: US Environmental Protection Agency, Nonpoint Source Pollution, Office of Wetlands, Oceans, and Watersheds. http://www.epa.gov/ nps/chesbay502/pdf/chesbay_chap02.pdf.

USEPA (US Environmental Protection Agency). 2011. Review of EPA's draft Approaches for Deriving Numeric Nutrient Criteria for Florida's Estuaries, Coastal Waters, and Southern Inland Flowing Waters. Washington, DC: US Environmental Protection Agency Scientific Advisory Board. http://yosemite.epa.gov/sab/ sabproduct.nsf/DCC3488B67473BDA8525 78D20058F3C9/\$File/EPA-SAB-11-010unsigned.pdf.

USEPA. 2012. National Summary of Impaired Waters and TMDLs. http://ofmpub.epa. gov/tmdl_waters10/attains_nation_cy.contr ol?p_report_type $=\mathrm{T}$. 